\title{
A Survey to the Origins of International law in Islam with the Emphasis on Human Rights
}

\author{
Sayed Reza Eslami ${ }^{1}$ \\ ${ }^{1}$ First Attorney at Law and Lecturer, Damavand Branch, Islamic Azad University, Damavand, Iran \\ Correspondence: Sayed Reza Eslami, First Attorney at Law and Lecturer, Damavand Branch, Islamic Azad \\ University, Damavand, Iran. E-mail: r_eslami2007@yahoo.com
}

\author{
Received: May 4, 2016 Accepted: May 30, 2016 Online Published: October 30, 2016 \\ doi:10.5539/jpl.v9n9p47 URL: http://dx.doi.org/10.5539/jpl.v9n9p47
}

\begin{abstract}
The Dutch called (Hugo Grosyius) is known in the most university textbooks as the father of international law. He acquired many of his intellectual foundations by reading (Seyrolkabir) book in Istanbul. Later on he presented realistic goals and ideas in his treatises and writings. That caused realistic developments in the West after the Renaissance, and therefore the, west knows him as (father of international law). But the intellectual foundation and what he used as the primary source and guidance of his thoughts were in fact Quranic verses and the big prophet traditions of Islamic religion and Imam Ali (Peace be upon him) which were collected as a summary in a text. Which was considered and done before Grosyius about 1100 years ago and acted upon it. (1)
\end{abstract}

Keywords: International law, human rights, jihad, Sacrifice, Fulfill promise, Treatment of Prisoners, The Hague Convention and Geneva Convention.

\section{Introduction}

Where some people abuse the name of holy God and his Prophet for their own evil purposes, and turn to a variety of crimes against humanity, the basic principles related to Islamic religion should be considered to determine the people who go over the wrong way .Everyone would understand that these extreme events have their made religion and the way of their favorite life, not what will be. While dealing with this issue of the Renaissance in the West is not something spontaneous and sudden, but also has other civilization deep roots which, incidentally, the Westerners familiar with that culture of the Crusades, revealed Progressive tendencies in them. In this article we will try briefly describe the issue of the laws of war in Islam, the real meaning of jihad and the treatment of prisoners and devastated people of war. That is only based on the Quran and the Holy Prophet behavior. Although throughout the history we have seen inappropriate behavior in the name of religion that never have had occasion to the rules of Islam.

\section{Overview of International Law and Its Definition}

Professor (Jorjcel), professor of international law at the Sorbonne University in France calls international law as the (Driot des gentes) or (People's Rights).

Kelsen the Austrian lawyer, the founder of Vienna School of Law and School the drafters of (Legal pure) knows all the legal rules based on a fundamental principle and believes that all the principles of law (domestic and international) have obtained their obligations from this principle. He has introduced this principle as the promise fulfillment principle. In fact, one of the general principles of law that has a very important role in the international law structure and in Latin language is called (Pacta sound servanda); In Quran it is mentioned as (اوفوا بالعقود). The Holy Quran in many verses, not only knows the promise fulfillment as an obligation, but also knows it as a holy tradition of the prophesy. For instance we can point to the following verses:

Remember Ismail who was committed to its commitments and was the prophet of God. (Maryam, 56)

Those who fulfill his promise with anyone are in fact truthful and Virtuous. (Baqara, 177)

Those with whom have a treaty separation of war, since they are stuck to their own treaty, you ought to stick to your own treaty, too. (Tobe, 7)

You shall fulfill your treaty, because you're responsible to them and in the resurrection you will be asked about promise and treaty. (Asra, 34) 
And those who completely fulfill their covenant are deserved to have supreme authority in the paradise and stay there etemally. (Momenon, 8, 10, 11)

Also, it is quoted from the Prophet of Allah (s): The one, who is not committed his own treaty, doesn't have any faith.

In some quotations, it's mentioned that respect the treaties toward the enemies is also necessary, as Ali (as) in Nahjolbalaghe in an order to (Malek Ashtar) says:

If there is a treaty between you and your enemy or you have assumed to do something, you should be faithful to your own treaty and do what you have assumed. And protect yourself to the treaty that you have assumed. (Lest you see any weakness in your commitments); because in holly's obligation it's very necessary that all of People with different opinions and tastes should commit their promise. Even pagans respect to the treaty with Muslims, because of their bad experience of violation of a treaty. So you should never betray and break your treaty and deceive the enemy, because no one dares to God except the poor ignorant and while God has placed the treaty and trust for the security and safety. And due to His favor has spread it to all of his creatures and placed it as a shelter which trusts on its stability, so crime, betrayal and trick is not allowed.

Also don't have any appointment with your enemy that there be any interpretation and excuse in it and when you emphasize on an agreement don't say different word and never let the problems make you have unfair termination in your agreements, because to have endurance against the problem that you hope to solve it and has a good conclusion is better than the craftiness and trick which results your fear. Away, you may be questioned by God, so you can't ask for forgiveness in this world and afterwards. Just a little attention to this speech is enough to warn the reader to strictly adhere of the obligations of the Muslim leaders and their personal and social conventions, because in this section the words of Imam Ali (Peace be upon him) _ the first Imam of the Shia _shows the importance and emphasis of the stability of treaties. Islam not only has plenty of advice on promise fulfillment, but especially emphasize with the respect to international relations, including recommendations to fulfill the promise, even against the most decadent countries in terms of belief and culture and also the toughest enemy of the Muslim community like pagans. According to Quran verses: (Althoug the group of pagans with whom you have treaty and none of them break any covenant and none of the enemies support you, even in this situation you should keep the promise as long as the agreement deadline, God loves virtuous (who kept their promise), (Tobeh, 4).According to this verse, the violation of promise even with the pagans is against the righteous.

The sixth Shia Imam_Imam Sadeq, (AS) says: If the nations' relationship tear apart and if each nation just think and talk about himself, will be destroyed and the worlds' countries will be ruined and also trade exchanges and Interests will be eradicated.) In fact the word of Imam confirms the importance and originality of the relations and international law and, somehow refers to the existence and importance of the international community which guarantees the existence of the individuals and, in fact, this is consistent to the speech of professor Jorjcel that referred to the international law (People's rights).

\subsection{How to Fight in Islam}

Basically, the concept of (jihad) in Islam does not merely a mean to fight, but rather the root of jihad (effort out) means to attempt. So jihad for God's sake means trying to achieve goals of God. Certainly, this effort has some levels that can be started from Patience and, also include the assumption of (Enjoining good and forbidding wrong).

Amiralmomenin Imam Ali (Peace be upon him) says:

(The greatest jihad is the right word telling before the cruel people)

It determines that those who just think jihad means fighting have led the meaning of this word to deflection. In general in the Islamic laws and practices there is a great emphasis on peaceful co-existence and reconciliation among the people. (So believe in God and reform your world affairs. (Enfal, 1) _ (so, reform each other's matters with justice and equity (Hajarat, 9).)

It refers to the above mentioned including the International Peace and how to invite other nations in Islam also confirms this article.

One of the principles of Islam is peace and agreement. In Islam it is leads you how to treat with enemies that have become your yesterday and today's close friends. (Fozzelat 33, Aleomran 20, Maedeh 99)

Also forbidden of war in the four months of a year and insert the land of Mecca (shrine) as a safe place emphasizes that Islam is based on peace and agreement. 
Islam emphasizes in being ready for war and providing military equipment and training techniques and tactics of war, but in verse 60 of Anfal it's said that all of the goals and the results of providing the troops and weapons is proposed at first to avoid war and scare the (enemy of God and the believers).

This interpretation indicates that one of the purposes of providing the military force is preventing Hostility. In 61 verse of Enfal Surah says: (If they offer you peace, so accept it.) It does not consider the possibility of conspiracy and the enemy trick in this regard is as an obstacle for accepting peace, although in this regard it invites the Muslims to have consciousness.

The principle in Islam is peace and non-recourse to war, unless the opponent attempts to attack and rape to evict the Muslims from their homes. At this time fighting will be essential. And can be an obligation as worship. Hence war is justified as self-defense.

(For those who war imposed upon them, jihad is allowed because they have been oppressed and God is mighty to help them.) (Surah Hajj, verse 39)

\subsection{But on What Basis You Should Fight?}

The centrality of war is fair treatment and the purpose of war should be administration of justice.

The main focus in Quran is in the final sentence of eighth verse in Al-Momtahena Surah: (Indeed, God loves justice people).

So even blasphemy doesn't cause the rights of a society be ignored and our behavior be unfair. As in the eighth verse of Maedeh surah says: Those who believe God you should always rise for Him and have a fair testimony. Lest enmity with some population cause you to quit justice. Pursuit justice that is closer to righteousness and fear of God because He's aware of what you are doing.) Quran forbids those who have excessive experiences of conflict with Muslims and Islam, and says:

Lest (Enemy nation or people who close that have closed your way mosque, make you to rape and, help for goodness and righteousness and don't insist sin and rape). (Maedeh, 2)

Basically, Islam behavior with different nations is a fair, cope with them as free and independent societies and suggests them to have peaceful co-existence. (God does not forbid you to have goodness and justice manner with those who don't fight you for religion and leave you out of your homes, because God loves justice people). (Momtahene 8)

So when foreigners and non-Muslims decide to fight and intent to destroy and expel Muslims from their homes, then Jihad in the way of God is must. Even in these cases, the basic principle is (Indeed, God is with justice people).

\section{Treatment with Prisoners}

A part of general international law is about using the armed forces and their treating against armed conflicts and serve to reduce the suffering of people in war and armed conflicts so, a branch of the principle protection of human rights in international armed conflict is created.

What today is regarded as the International Humanitarian Law actually refers to the 4 Conventions of Geneva in 1949 which includes:

The wounded and sick people in the battle field.

Wounded and patients of shipwreck at the sea

Support of Captives.

Also The Red Cross conventions almost have ratified to the countries all around the world. In 1977, two supplementary protocols were adopted: as well:

The international armed conflict protocol

Quran in Baqara Sura refers to the story of Jewish and their inhumane treatment with Jewish captives which were captured in contrary to the teachings of the Old Testament, and says:

(We have assumed Bani Israel not to worship except God and behave well with parents and relatives, orphans and miserable people and deal with people logically, pray and pay charity (zakat).

But except a few number of you turned back objectively.

And we have been assumed by you not to shed each other blood unjustly. And some of you not devastate others.

And you accept this treaty consciously but you are those who killed each other and have devastated a group of 
your countrymen from their homes, once a number of captives were released them by you through ransom and compensation, while the expulsion of them from their country was forbidden. Do you believe in some parts of the Old Testament and disbelieve some other parts? (Baqara, 83, 85)

In the fourth verse of Muhammad surah (Bless be upon him and his family) we read:

(The believers, who believe God, when you faced with infidelity in the war, at first you should subdue and defeat them until you get so hard on them. Then attempt to get and fasten the captives and then either release them without any exchange or take them the ransom for their release, Until the war put down it goods on the ground (This allusion means the warriors, lay down their arms.)

In this holy verse, God emphasizes the Muslims' full instructions in war like killing captives, slavery- which customary in and it is not mentioned anywhere the slavery-which was customary in that time.

The verse 67 of Anfal Surah, tells the events of unbelievers captivity by the Muslims and their consequence (No prophet is allowed to take captives from enemy until completely overcome them. You want the goods of unstable world and want to get more prisoners and release them against the ransom But, God wants you the other world; And God is mighty and wise.

If God did not command before (without any notification no nation will be punished) for those prisoners that you have taken, you would have been gotten a huge punishment...

You prophet! Tell to your captives: (If God knows there are good aims in your hearts (to have pure intention in your mind) gives you better than what has taken you; and forgive you; and God is compassionate and merciful). But if they betray you _ earlier they (as well) have betrayed God_and God will give you a victory over them, God is smart and Wise.)

As we see the tone of this verse that the target is the Prophet (Bless be upon him and his family) and captives are with kindness and compassion manner and it shows that the Islamic way of dealing with captives, no matter what will be the final task is Justice and humanitarian.

According to the verse above, it's clear that there is not any special order about the Muslim humanitarian manner and common prisoners. In other verses of holy Quran, the emphasize is having a good behavior to captives as is the best way that makes Allah happy and avoid them for eternal punishment. As discussed in Ensan surah, verse 8: (Believers in sake of God feed poor and orphan and the prisoners.)

The battle of Badr was the first serious war between Muslims and polytheists of Mecca which a large proportion of pagans were captured by Muslims. More than seventy of them were captured by Muslims. Prophet Muhammad (Bless be upon him and his family) also behaved with these captives graciously and freed them instead of a little ransom and freed those who were illiterate and poor without any ransom and freed each literacy captives instead of teaching literacy to ten Muslims.

At Honein war, about 6 thousand of unbelievers and polytheists and idolaters were captured by Muslims. Despite Muslims unwillingness' prophet convinced them to free the captives. In some wars, the Prophet ordered the punishment of certain individuals due to the crimes. They mentioned, ie in Islam, the principle is to bear with captives. No one will be punished just because of fighting in the war and then arrested.

But such items like: Spying or break the former covenant will cause that person to be punished.

Here we mention some parts of the Islamic tradition as well as the tenderness and kindness to the captives:

_My order is about tenderness to captives and accept it.

_On the resurrection day, three people will be in the shadow of the throne of God;

(Such as) the person who feeds miserable and captives.

The first shias' Imam Ali (Peace be upon him) said:

Anyone who has been blessed wealth (by Allah), responsible cherish their relatives and do hospitality and free captives from captivity.

However, among all the past civilizations and peoples, killing and misbehaving to the captives of war was routine and even was as a sign of pride and joy and overcome and victory:

"Georgiy Zidane " the Egyptian Christian writer in the history book of civilization writes: (In the first war of Sasanian Shapur(Known as the 1st Shupur ,the great) who defeated and captured the Roman empire and captured about 90 thousand Roman soldiers, the Jewish bought the Christian captives from Iran and cut their all head like sheep) 
Will Durant in the history of civilization, writes: (When Jerusalem had been conquered by crusader army; the women were killed by dagger, and got the infant's by legs force fully and separated them from their mother's breast and were thrown them over the wall and broke down their neck by beating them to columns, consequently, they killed 70 thousand Muslims who had remained in the town.

Those Jews, who had survived were, collected in a synagogue and burned them alive.)

There was an alternative for captive Arab Muslims who were captured by crusaders in Spain whether to change their religion in to Christianity or to be killed by sword or fire.

Romans tied the alive prisoners to the dead bodies that like a dead body stink up and be annihilated.

Also using the prisoners of war as the emperor's entertainment and Roman people in gladiatorial battles was another violent behavior to captives.

\section{Spoils of War}

The first person who thought about formulating new rules in international law, in the case of captives was (Mosiyo donan), from Geneva.

When he saw the tragic situation in battlefield (Solfrin), he published a book called (souvenir of Solfrin) and stated that it is good for the governments to support the military sick and wounded people and establish an agreement. This book was published soon and a major discussion about it took place . The governments stated conferences that were completed in 1863, 1864 and finally in 1868 in Geneva which we can say: the agreement of Hague in 1899 is the same as 1868 agreement, word by word.

In general in this agreement decided that, the required movable objects could only be provided for the wounded and sick parties of the victorious forces.

According to chapter 53 of the Hague agreement, the triumphant forces can take over all movable properties belonging to the owner of the invaded territories that may be consumed by war operations. So the triumphant forces can occupy the cost of war, food stocks, horses, carriages and ... but the immovable properties should not be captured or destroyed.

Regarding exquisite works and books and other objects related to science and technology which can be found in museums and libraries should be respected individuals' properties by the invaders.

In the quadruple Geneva agreements in 1949, there are also some cases which can be observed as the provisions of Geneva agreement in nineteenth century or its supplement.

Sharl Russo, a French modern scientist in the law book of "Armed Conflict," writes:

(Hostile enemy could confiscate the enemy properties where located in their territory- (Whether private or public, movable or immovable) that were relocated on their territory.

This method was applied By British towards French nationals in 1793. Although perfect war in the modern era made common the enemies property confiscation at the beginning of the twentieth century, the government's authority is not limited and some rules should be considered, which are summarized as follow:

No harm to the rights of the nations of neutral countries no banning of the personal properties of those who faithful to the law. However, personal properties that has been regarded in land war as rule, is not respected in naval war at all.

In the old tradition of naval battle seizing the property of others was recognized legally and in this justification it is said that the only way of breaking the enemies' resistance is disconnecting the naval communications; because without this communication no country can continue to live. While Islam in kinds of the wars, either naval or by land, not only respected the neutral government properties of the nations in the neutral government, but also didn't allow all people confiscate the properties in the conquered territories; and, those who proved that did not participate in the war, and, also did not have any war with the Islamic government were protected financially and physically, Such as Clergymen, farmers and etc.

The most important reform program that Islam has brought to the spoils of war was (to unlike the conventional method at that time, especially in the Arab tribalism that often war happened for earning the material interests and looting the others properties_and sentenced and banned war for earning properties), and stated, we can fight only with those who openly have taken the arms against Islam and Muslims And are a serious threat to the Islamic system), In this regard, there are lots of evidences in the Qur'an and narrations which we refer to some of them. 
A - War in Islam as a sacred fight-gihad- is in the basis of God's sake, in all cases will depend on (For God's sake), and this indicates the fact that the motivation for jihad should only be for divine and spiritual values, Not spoils of war and financial issues, For example: in Nesa sura (verse 75) we read: (Why not jihad in the sake of God, While A group of disable men, women and children are captured by unbelievers in Mecca. They always say to God bring out us from this city that their people are wicked and from your own behalf send to our misery people some protection and helper. Also, in many cases that the issues of jihad and fight with enemies have been raised, there are some terms such as: For God's sake, obtain God's satisfactions and etc. Including the verses of 154, 190, 218, 244 and 246 of Baqara sura and in many other verses of Quran which is no need to mention all.

B_ in Nesa sura (verse 94) asserts this article that the Muslims shouldn't attack with those who have accepted peace and faith and put ground their guns due to obtain while theterm jihad is not in line with this concept.

(When step in the way of God (And go to for jihad) do research and because of gaining unstable world investment and spoils to the one who states the peace and Islam, don't tell you are not Muslims ; because there are lots of spoils(for you) in the hands of God. You have already been like this And God had conferred upon you and have been leading so for thanks to this great gift do research.

Allah is Allwise.)

C_As in Anfal Sura, verse 67 states:

(No prophet has right to take any prisoner (of the enemy) to completely win over them and place your feet firmly on the ground, you want the unstable goods from the world. and want to get more prisoners and release them against getting the ransom) but God, wants the hereafter for you...

In this verse, clearly points out a group of Muslim soldiers who would gain to the economic interests of the front enemy, and is mentioned as an indecent purpose and considers their action punishment as a severe before God.

$D_{-}$in the Islamic traditions it is mentioned in many cases as in Quran so, For instance: Imam Baqer, the fifth Imam of Shia (Peace be upon him) has quoted from the Prophet (Bless be upon him and his family) that the Prophet of banning the Muslim militants for economic goals, said:

(The values of actions are compatible with to the intentions of actors, and each person's reward is in accord with to their purposes, so, everyone who has fought just for the sake of God and his purpose was pleasing God will get his reward, And he would purpose is to gain the worldly interest, even if it was a the adhere of the camel shoe, will not have any reward except this.)

Imam Ali (Peace will be upon him), the first Shia Imam Stated:

(Do not mutilate any dead body and do not tear their veil when win against the men of the enemy do not enter in their homes without permission and do not seize anything from enemy properties except what is available in the camp and never induce the women to ruff by abusing and offending them, even if they insulted your honor, leaders and miners.)

Imam Sadeque (Peace will be upon him) had quoted from Imam Ali (Peace will be upon him) pointing his military commanders:

(I swear you to God lest you have might not be any injustice to farmers of enemy territory under your domain)

Also respecting the natural resources and protecting the environment even during the war time the other orders and recommendations of true Islam.

While the Holy Quran state son of the goals of human creation as, not only introducing that the development and prosperity in the land is one of the objectives of the human creation but also has identified that its destruction is of the largest deviation and it's against the values. In Hood surah, verse 61 states:

(God has created you from the soil and asked you to build it by yourselves.)

And in Baqarah surah, verse 205 says:

(Some people when have captured any power then try to create destruction on the land and destroy agriculture and cattle, and God doesn't love the vice and corruption.)

( the sixth Imam of Shia), Imam Sadiq said as from the Prophet (Bless be upon him and his family) quoting that constantly there is not permission to the Islamic army the appealing of abjuration, rebellious, mutilating the enemy and killing the children and monks, since before Islam era, One of the traditions of the ignorant Arabs was cutting the members and organs of the dead bodies of enemy soldiers and making necklaces by chopped parts of killed enemies' parts of bodies and dancing around the fire to celebrate. 
In fact Islam's' emphasis was to remove these bad and inhumane habits among the Arab tribes and create human and culture construction school.

The great Prophet (Bless be upon him and his family) said: (Don't burn any palm tree, don't sink them in water, don't cut any fruit tree and don't fire any farm. Avoid killing animals, unless you have to use its meat.)

Another outstanding example is about how the Muslims deal with the inhabitants of the conquered lands. Ali (Peace be upon him) in a Jihad sermon Cry out in protest when he heard the Muawiya troops have attacked the warehouse city and insulted the general public, including non-Muslim women who lived as a religious minority in the Muslim community and their jewelry were kidnapped, and Said: (If a Muslim man hear these news and die of sorrows there is no blame for him, but also is well-deserved.)

Unfortunately, some Medias attributing unreal things to Muslims, either intentionally or due to unawareness and also because of using second hand sources. Such as, burning the library of Alexandria at the time of conquering Egypt,While in the first hand sources, such as the Britannica encyclopedia and authentic historical books like: "History of civilization in the chapter of medieval", burning, the library of Alexandria had happened At the time of (Justinian)- the Christian emperor of Rome in the name of (Onam Satenam) or (The holy Throne). When the Muslim armies entered into Egypt, the library of Alexandria had already been destroyed. However, in contrast to the progressive rules of Islam, some behavior occurred at later dates, for example: when Crusader armies attacked the East by the Pope's command to take Jerusalem from the Muslims, (in the name of Christianity and promoting kindness), did not mercy even to their fellow And when they arrived to Constantinople, the Eastern Roman capital assaulted Santa Sophia church with the blame of having Orthodox Christian religion. They killed all of the priests, raped the nuns and looted their all valued and expensive goods, such as: The golden cross and silver candlesticks.

\section{Conclusion}

Grotius, Hugo from Dutch (1383_1645) was a lawyer, diplomat mathematician, Speaker, Historian and a good scientist in the Renaissance era. Whom with some exaggeration is known as the father of (International Law). He emphasized on the dichotomy of international law, natural rights and foreigners rights.

At first he was imprisoned in the city of Leiden and could escape from that place by the help of his wife and went to (Istanbul) the capital of the Ottoman Empire. There he acquainted with a book which is called (Searol Kabir) that an Iranian Muslim named Mohammad Sheybani wrote it. The contents of this book are derived from Quran verses, prophet tradition and the first imam of the Shia. Mohammad Sheybani was a scientists and teacher of Caliph of Baghdad (Bani Abbas dynasty). About 650 years ago before Grotius, he wrote a book called (Searol Saghir) that was short and compact. Since some of the caliph's courts had for jealousy of him, plotted against him befor caliph that how an Iranian who his native language is Persian can write a book in Arabic. Due to this, he decided to write more detailed and complete book called (Searol Kabir).

As acquainting with some cases of Sheibanis' book, Hugo Grotius used some issues that had been raised about expressing some positions (About war and peace) but that's not accurate and complete, anyway.

Rules of Islam, in the field of humanitarian law have been very innovative and creative.

Except for defense, Muslims should take action to promote and spread Islam according to this the verse: (Invite people to come into the way of God with wisdom and fair preaching and discussing them in the best ways) without resorting to war and fight. And also after the war and victory over the enemy, their role models should be as the Prophet. He overcame the pagans and idolaters of Mecca with full power and glory. When he conquered the town, he expressed the peak of his mercy and love although when his sworn enemies were attended among them and were fighting with him for many years and even his closest family members were killed by them, he forgave them and ordered general amnesty. What was recommended in the previous religion Christianing meant to love, the great Prophet of Islam has done it completely in the peak power. Unfortunately now a days, we are witnessing some events that individuals or groups do inhumane acts in the name of Islam, Which seem originating more from their personal and tribal beliefs.

\section{References}

Encyclopedia Britannica. (1974). the University of Chicago; 15thed, U.S.A.

Geneva conventions. (1947).

Georgiy Zidane, Darol maktabatolhayat, Beirut Bita. (2004) History of Islamic civilization.

Ghzralhakam and Darralklam Abdolvahedin Mohammad Amadi. (2003). Darolhadis_Qom. 
Hague conventions. (1907).

Kelsen, H. (1961). General theory of law and state. New York.

Mohammad Baqer Majlisi Bharalanvar. (1982). Dar Ehia Altras Aleslam, Beirut.

Nahjolbalaghe, Abolhasan Mohammaebn Hasan Musa Razi_ Correction by Sobhi Saleh. (2008). Lebanese Library, First Edition, Beirut.

Robert Beldso Boslav Bozchek. (1996). Translated by dr. Bahman Aqaii, the International Law Dictionary, Publications of Ganj Danesh, Tehran

Sharl Roso. (2003). Translate: Sayed Ali Hanjani Law of armed conflict.

The Holy Quran.

Will Durant. (2006). History of Civilization, the Company of Scientific and Cultural Publications, Abolqasem Taheri: Translator.

\section{Copyrights}

Copyright for this article is retained by the author(s), with first publication rights granted to the journal.

This is an open-access article distributed under the terms and conditions of the Creative Commons Attribution license (http://creativecommons.org/licenses/by/4.0/). 